\title{
Perancangan Video Company Profile Sebagai Penunjang Informasi Pada SMK Kartika X - 1
}

\author{
Po Abas Sunarya ${ }^{1}$, Sandro Alfeno ${ }^{2}$, Lola Sartika ${ }^{* 3}$ \\ ${ }^{1}$ Program Studi Magister Teknologi Informasi Fakultas Sains dan Teknologi Universitas \\ Raharja, ${ }^{2,3}$ Program Studi Teknik Informatika Fakultas Sains and Teknologi Universitas \\ Raharja \\ E-mail: ${ }^{1}$ abas@ raharja.info, ${ }^{2}$ sandro@ raharja.info, ${ }^{* 3}$ lola.sartika@ raharja.info
}

\begin{abstract}
Abstrak
Pada era modern saat ini teknologi informasi secara online banyak digunakan oleh perusahaan atau lembaga lainya untuk menyampaikan informasi dan menjadi alat bantu promosi, dengan menggunakan media audio visual dengan metode berbasi animasi 2 dimensi yang mampu menarik audience. Untuk mendapatkan informasi tersebut bisa di akses diberbagai media sosial. SMK Kartika X-1 Jakarta Barat institusi pendidikan kejuruan swasta yang masih menggunakan media cetak seperti benner, brosur, spanduk yang berbentuk gambar dan teks sebagai media informasi. Akan tetapi dengan media cetak ini untuk memberikan informasi kurang efektif karena jangkauannya kurang luas. Berdasarkan permasalahan diatas dibutuhkan suatu penelitian yang merancang video company profile untuk melengkapi media informasi sekolah tersebut. Penelitian ini menggunakan metode berupa : analisa permasalahan, pengumpulan data, analisa SWOT, konsep produksi media (KPM). Perancangan video ini di bantu dengan software editor seperti berikut Adobe Illustrator (Ai), Adobe After Effect (Ae) dan Adobe Premiere Pro (Pr). Video informasi ini akan diimplementasikan melalui YouTube dan media sosial Official SMK Kartika X-1. Dengan adanya video company profile ini dapat membantu sekolah ini dalam memperkenalkan profil sekolah.
\end{abstract}

Kata Kunci-Company Profile, Animasi 2 Dimensi

\begin{abstract}
In today's modern era, online information technology is widely used by companies or other institutions to convey information and serve as promotional tools, using audio-visual media with a 2-dimensional animation-based method that is able to attract audiences. To get this information, you can access it in various social media. SMK Kartika X-1 West Jakarta is a private vocational education institution that still uses printed media such as benner, brochures, banners in the form of images and text as information media. However, using this print media to provide information is less effective because of its less extensive reach. Based on the above problems, a study is needed to design a video company profile to complement the school's information media.This research uses methods such as: problem analysis, data collection, SWOT analysis, media production concept (KPM). The design of this video is assisted by editor software such as Adobe Illustrator (Ai), Adobe After Effects (Ae) and Adobe Premiere Pro (Pr). This information video will be implemented through YouTube and social media of the Official SMK Kartika X-1. With this video company profile it can help this school in introducing the school profile.
\end{abstract}

Keywords—Company Profile, 2-Dimensional Animation 


\section{PENDAHULUAN}

Media informasi sangat penting karena salah satu alat untuk mengumpulkan dan menyusun kembali sebuah informasi sehingga menjadi bahan yang bermanfaat bagi penerima informasi. Media informasi saat ini membuat versi yang lebih mudah untuk diakses, dengan menggunakan jaringan internet, informasi bisa didapatkan secara online, seperti google, sosial media, blog, podcast dan lain-lainnya, untuk menjangkau informasi tersebut dapat menggunakan peralatan teknologi komputer, ipad dan smartphone yang memiliki akses internet. Perkembangan teknologi komputer khususnya multimedia audio visual and broadcasting sudah berkembang pesat dan banyak yang menggunakannya untuk media informasi atau alat bantu promosi sebuah perusahaan, produk dan lainnya. Penggunaan media audio visual dalam dunia pendidikan tidak kalah penting, karena masyarakat membutuhkan sebuah informasi sekolah yang lengkap, jelas, akurat dan mudah untuk dipahami.

SMK Kartika X-1 Jakarta Barat merupakan lembaga pendidikan swasta yang berada di Jakarta Barat berdiri pada tahun 1998 memiliki luas bangunan sekita $3200 \mathrm{~m}^{2}$ dan di bawah naungan TNI Angkatan Darat melalui Yayasan Kartika Jaya Jayakarta dan berlokasi di Jl. Daan Mogot KM. 17 Komplek Kodam Jaya, Kota Jakarta Barat, DKI Jakarta, 11840.

Berdasarkan observasi peneliti di SMK Kartika X-1 Jakarta Barat memiliki 11 ruangan kelas yang setiap kelas nya diisi dengan 36 siswa/siswi dan sekarang ada penambahan ruang kelas sebanyak 4 ruang kelas, jadi total ruang kelas terdapat 15 ruang kelas. Dari data sebelumnya SMK Kartika memiliki target siswa/siswi sebesar 108 murid pertahun, dikarenakan ada penambahan ruang kelas maka target yang sebelum berubah menjadi 180 murid pertahun. Maka dari itu SMK Kartika memerlukan media informasi yang efektif guna untuk meningkatkan target tersebut.

Media informasi yang digunakan SMK Kartika X-1 pada awalnya masih berupa banner, brosur dan juga spanduk yang tergolong kedalam media cetak. Sehingga hal ini kurang efektif untuk memberikan informasi. Sebagai tindak lanjut untuk mengembangkan sarana penunjang informasi, oleh karena itu peneliti melakukan sebuah perancangan media informasi lain yang lebih efektif dan lebih menarik dilihat oleh para audiens yaitu media informasi audio visual animasi 2 dimensi gunanya untuk melengkapi media informasi.

Animasi 2 dimensi merupakan jenis animasi dalam bentuk 2 dimensi. Animasi yang dibuat seperti gambar dan karakter dalam format dua dimensi dan menghidupkan nya dengan gerakan. Untuk menghasilkan animasi 2 dimensi maka setiap layer perludi gambar satu persatu sehingga. Maka dari itu media informasi animasi 2 dimensi dipilih menjadi media informasi yang menarik karena jenis animasi ini bukan hanya berbentuk teks saja namun dapat memuat campuran gambar yang bergerak, musik, warna, dan suara efek. Hal tersebut didukung oleh penelitian yang dilakukan oleh Nurrahman (2020), dimana animasi 2 dimensi memiliki 3 proses tahapan. Pertama, tahap pra-produksi yaitu mencari dan menyiapkan referensi, menyusun konsep dalam bentuk storyline dan membuat perancangan melalui storyboard dan melakukan design graphic. Kedua, tahap produksi yaitu compositing dan animating, melakukan Dubbing suara, memberi sound effect, memberi musik, dan rendering. Ketiga, tahap pasca-produksi yaitu pendistribusian iklan.

Dengan menggunakan media audio visual animasi 2 dimensi diharapkan dapat mengembangkan media informasi dan mempermudah masyarakat luas mengetahui informasi yang disampaikan oleh sekolah SMK Kartika X-1. Media audio visual animasi 2 dimensi ini menampilkan sebuah informasi dengan video yang mudah dipahami pada bagian unsur gerak, visualisasi atau gambar, audio dan text, sehingga menambah daya tarik peminat.Berdasarkan latar belakang tersebut maka peneliti ingin melakukan penelitian suatu perancangan video company profile berbasi animasi 2 dimensi pada SMK Kartika X-1. 


\subsection{Literature Review}

Dalam meningkatkan penelitian ini, peneliti melakukan beberapa literature review terhadap penelitian - penelitian sebelumnya, berikut ini literature review:

1. Peneliti yang dilakukan oleh Azro, dkk (2020). "Perancangan Video Animasi 2 Dimensi Penggalangan Dana Dari Sampah Kampus Politeknik Negeri Sriwijaya". Tujuan dari penelitian ini merancang video penggalangan dana yang terdiri dari sampah daur ulang guna untuk membuat metode manajemen pengelolaan sampah yang lebih bagus. Hasil dari penelitian ini sebuah video yang berbasi animasi 2 dimensi. [3]

2. Penelitian yang dilakukan oleh Baqi, dkk (2020). "Media Informasi dan Promosi Berbasis Motion Graphic pada PT. NL Indonesia". Tujuan dari penelitian ini merancang video motiongraphic guna untuk memberikan informasi serta media promosi pada PT.NL Indonesia. Hasil dari penelitian yaitu video profile PT. NL Indonesia berbasi motion gtaphic.[4]

3. Penelitiaan yang dilakukan oleh Supriati,dkk(2020). "Film Dokumenter Sebagai Media Informasi Dalam Memperkenalkan Tempat Wisata Banten Lama". Tujuna dari penelitian ini adalah memberikan informasi serta mempromosikan tempat wisata yang bersejarah yang berada di Banten Lama. Hasil penelitian berupa video film dokumenter. [6]

4. Penelitian yang dilakukan oleh Kusumo,Fajar dan Sulartopo(2019). "Perancangan Video Company Profile Sebagai Media Promosi dan Informasi Pada Toko Citra Meubel Semarang". Tujuan dari penelitian ini untuk menyampaikan informasi serta menjadi media promosi pada Toko Citra Meubel Semarang dan penelitian ini menghasilkan video.[5]

5. Penelitian yang dilakukan oleh Anita, Diajeng Ria dan Fitri Marisa (2017). "Rancangan Video Media Promosi Berbasis Motion Graphic 2D Untuk Meningkatkan Jumlah Mahasiswa Universitas Widyagama Malang". Tujuan penelitian ini untuk merancang video gunak untuk media promosi dan hasil dari penelitian ini sebuah video yang berbasih motion graphic animasi 2 dimensi yang berjeni SFA (Short Form Animation). [2]

\section{METODE PENELITIAN}

Dalam meningkatkan penelitian ini, maka terdapat beberapa metode yang digunakan dalam proses pengumpulan data, yang diperlukan dalam Media Informasi Animasi 2 Dimensi pada SMK Kartika X-1 Jakarta Barat :

1. Metode Analisis Permasalahan, menganalisis permasalahan yang terdapat pada SMK Kartika X-1 Jakarta Barat.

2. Metode Pengumpulan Data, pengumpulan data dengan beberapa cara, seperti berikut :

1) Observasi suatu proses pengumpulan informasi yang dibutuhkan, dengan melakukan penyelidikan secara langsung ke tempat penelitian.

2) Interview suatu langkah untuk pengumpulan informasi yang prosesnya membuat sesi tanya jawab agar mendapatkan suatu informasi yang kita butuhkan, dengan berinteraksi atau bertatapan muka antara dua orang bisa lebih serta mengajukan sebuah pertanyaan.

3) Studi pustaka suatu pengumpulan data dan materi yang digunakan untuk reverensi, terdapat beberapa sumber seperti buku panduan, majalah serta sejarah yang terkait dalam penyusunan penelitian.

3. KPM memiliki beberapa tahapan atau yang sering digunakan untuk perancangan video yaitu tahapan awal (Preproduction), Production, tahapan akhir atau finishing (Postproduction). 


\section{HASIL DAN PEMBAHASAN}

\subsection{Pre Production}

Pre Production suatu tahapan utama dalam perancangan serta persiapan produksi yang dimulai dari penyusunan sinopsis, Script Writing dan Storyboard.

\subsubsection{Ide/gagasan}

Merupakan tahap awal dalam perancangan video, dalam hal ini menentukan ide atau gagasan yang akan dijadikan sebagai video informasi yang berkonsep animasi 2 dimensi. Ide atau gagasan merupakan suatu pengumpulan data yang diperoleh dari sumber informasi dan dituangkan ke dalam sinopsis. Dalam video informasi ini masyarakat dan calon siswa/siswi dapat mengetahui informasi tentang profile dan kegiatan yang terdapat pada SMK Kartika X-1 Jakarta Barat. [10]

\subsubsection{Sinopsis}

Sinopsis merupakan poin utama untuk menggambar alur cerita, karena sinopsis ringkasan singkat alur cerita menjadi bentuk pemendekan dari sebuah feature dokumenter dan dibatasi dari jumlah halamannya. [1]

"Video animasi informasi SMK Kartika X-1 Jakarta Barat mengilustrasikan tentang informasi seputar sekolah SMK Kartika X-1 Jakarta Barat seperti sejarah singkat tentang sekolah, lokasi sekolah, fasilitas yang diberikan sekolah, dan kegiatan ekstrakulikuler yang terdapat di sekolah."

\subsubsection{Narasi}

Narasi merupakan sebuah rangkaian cerita atau peristiwa kejadian secara kronologis, baik fakta maupun rekayasa atau fiksi. Narasi juga menjelaskan alur cerita yang terdapat didalam video. [6]

"SMK Kartika X - 1 merupakan salah satu lembaga pendidikan kejuruan yang berada di Jakarta Barat / berdiri pada tahun 1998 / memiliki luas bangun $3200 \mathrm{~m}^{2}$ / dan di bawah naungan Yayasan Kartika. // SMK Kartika X - 1 berlokasi di Jl. Daan Mogot Km 17 / Komplek Kodam / Kalideres / Jakarta Barat. // SMK Kartika X - 1 memiliki 3 kompetensi keahlian / sebagai berikut : / akuntansi / administrasi perkantoran / dan teknik komputer jaringan. // SMK Kartika $\mathrm{X}$ - 1 menyediakan fasilitas yang memadai / antara lain : / ruang kelas yang nyaman / lab komputer / perpustakaan / lapangan olahraga / halaman parkir / serta fasilitas - fasilitas lainnya. // SMK Kartika X-1 / mendukung kegiatan ekstrakurikuler / diantaranya : / bidang bela negara / terdapat / paskibra / pramuka / dan PMR / bidang olahraga / terdapat / basket / futsal / pencak silat / dan taekwondo / bidang keagamaan/ terdapat / rohis.//"

\subsubsection{Storyboard}

Storyboard atau papan cerita merupakan salah satu cara alternatif untuk menggambarkan sebuah scene yang akan ditampilan dalam video secara manual dengan alat bantu tulis dan selembar kertas untuk mengvisualisasikan. [8] 


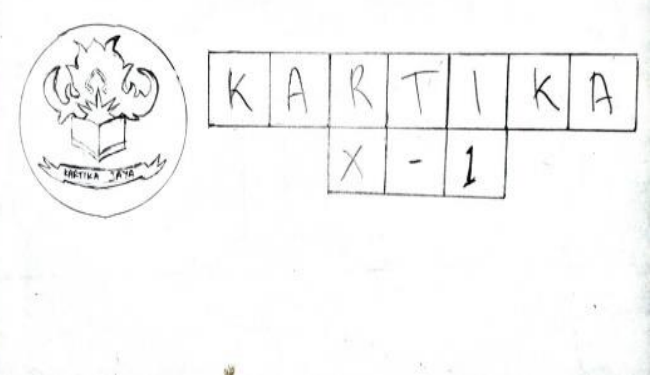

Gambar 1. /Scene 1/Menampilkan Bumper Intro

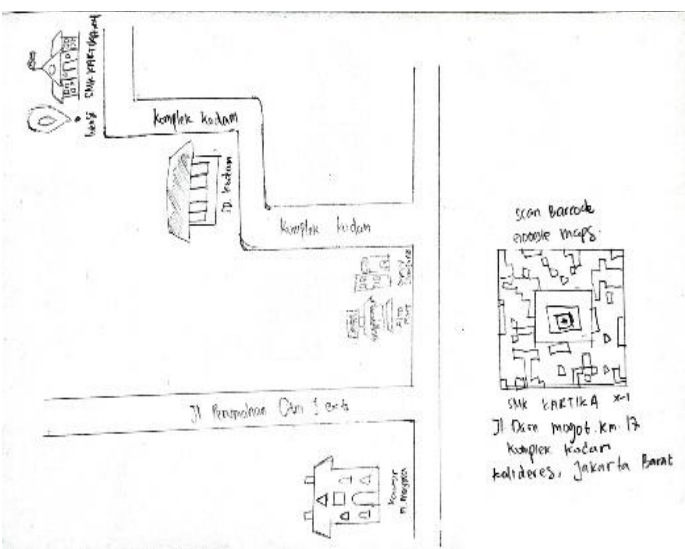

Gambar 3. /Scene 3/Menampilkan Denah Lokasi

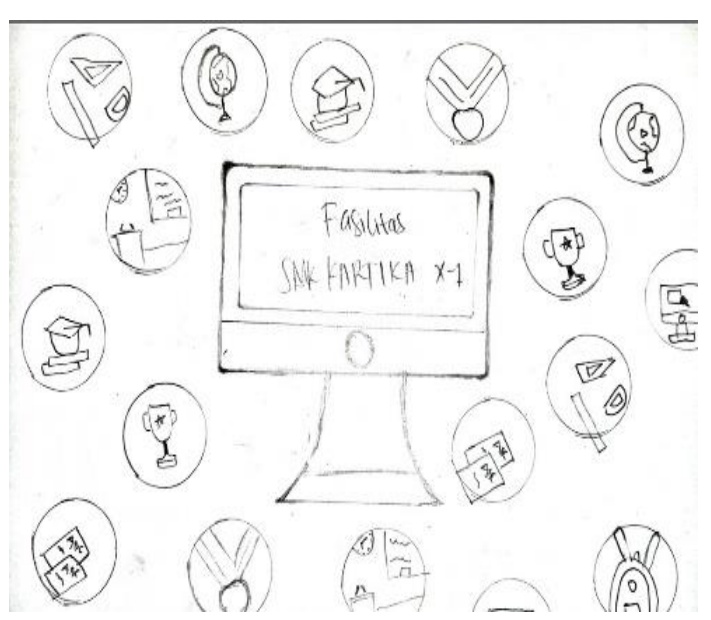

Gambar 5. /Scene 5/Menampilkan Fasilitas - fasilitas

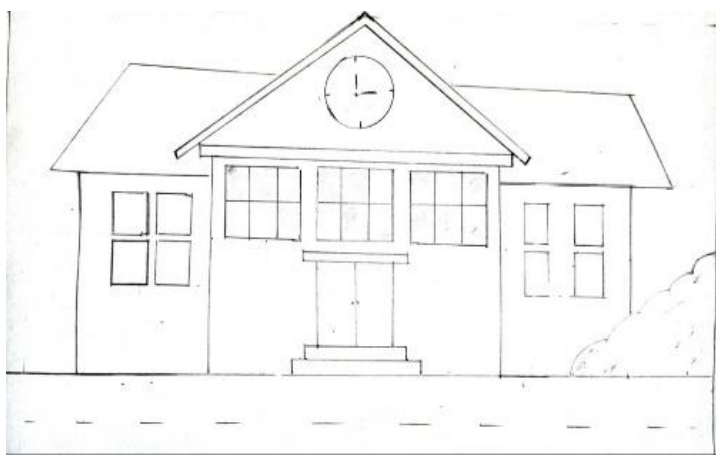

Gambar 2. / Scene 2/Menampilkan Bangunan Sekolah

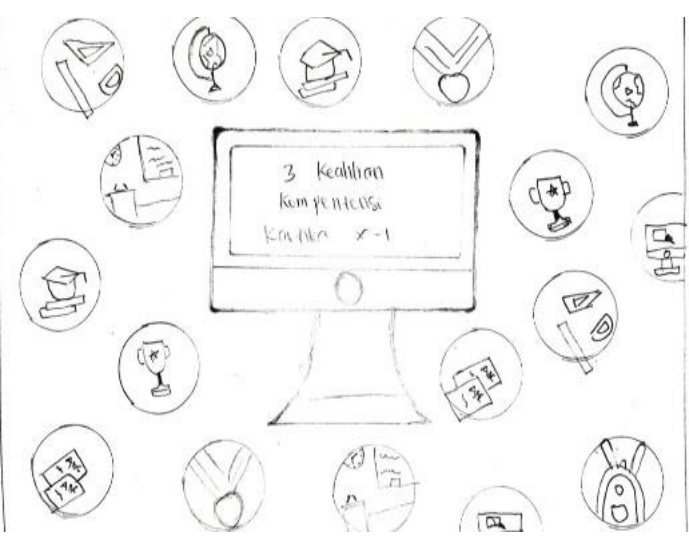

Gambar 4. /Scene 4/Menampilkan Keahlian Kompetensi

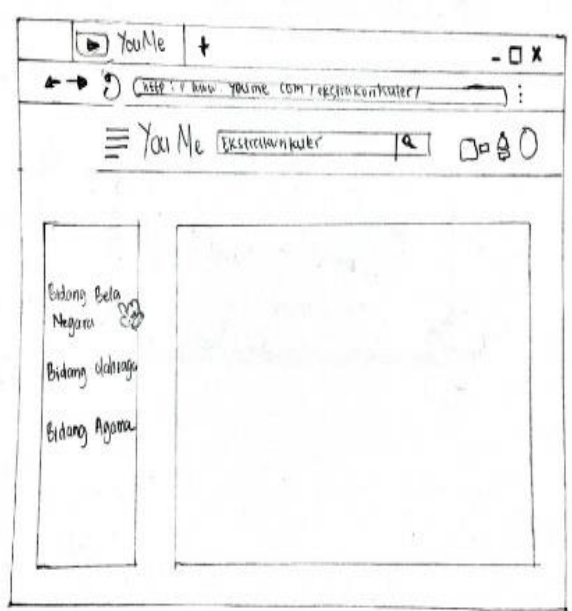

Gambar 6. /Scene 6/ Menampilkan Kegiatan Ekstrakurikuler 


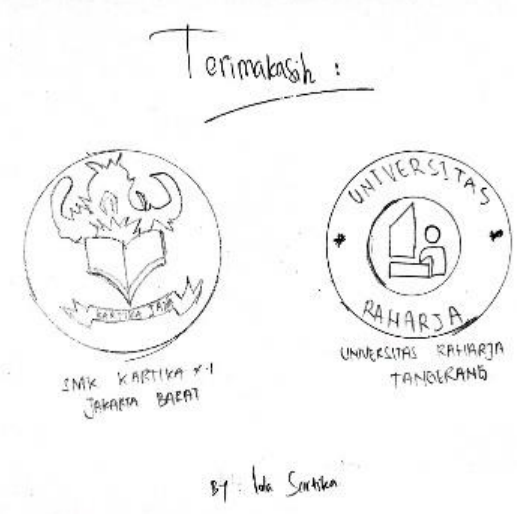

Gambar 7. / Scene 7/Menampilkan

Bumper outro atau closing

\subsubsection{Peralatan yang digunakan}

Dalam proses pembuatan suatu video pastinya membutuhkan alat untuk memproses nya, berikut ini alat yang digunakan untuk membuat suatu video. 1). Laptop Asus A455L, 2). Inone Wireless Optical Mouse, 3). Microphone taffware bm-800, 4). Flashdisk SanDisk Ultra Dual Drive 32GB.

\subsection{Production}

Production tahapan pengumpulan file yang dibuat di tahapan pra produksi, lalu dikerjakan secara bersamaan denga semua anggota tim atau crew untuk bekerja sama dalam pembuatan dan mewujudkan secara nyata bentuk visual yang menghasilkan karya berupa video. [7]

\subsubsection{Strategi Multimedia}

A. Geografi :

a) Khusus : Kalideres, Jakarta Barat

b) Umum : Wilayah DKI Jakarta dan sekitarnya

B. Demografi :

a) Jenis Kelamin : Laki - laki dan Perempuan

b) Kelas Ekonomi : Semua Kalangan

c) Usia : 15 tahun sampai 21 tahun

d) Sasaran : Siswa/siswi yang baru lulus SMP yang sedang mencari SMK untuk melanjutkan pendidikan nya.

C. Psikografi :

Masyarakat luas dan calon siswa/siswi yang ingin lebih mengetahui info seputar tentang SMK Kartika X-1 Jakarta Barat.

\subsubsection{Tujuan Visual}

Tujuan visual ini merupakan suatu penggabungan gambar, teks, suara dan ditambah dengan visual effect guna untuk menambah kesan dan pesan yang lebih menarik didalam video informasi yang ditampilkan. [9] 
Tabel 1. : Tujuan Visual

\begin{tabular}{|l|l|}
\hline \multicolumn{1}{|c|}{ Visual Effect } & \multicolumn{1}{c|}{ Kesan Yang Ditimbulkan } \\
\hline Intro Bumper & Simpel dan jelas \\
\hline $\begin{array}{l}\text { Animasi penjelasan profile SMK Kartika } \\
\text { X - 1 Jakarta Barat }\end{array}$ & $\begin{array}{l}\text { Simpel, jelas, menarik dan } \\
\text { informatif }\end{array}$ \\
\hline Outro Bumper & Simpel dan Jelas. \\
\hline
\end{tabular}

\subsubsection{Strategi Visual}

Strategi visual yang dirancang dapat menghasilkan video informasi yang dapat menarik minat peserta didik berserta walinya dan masyarakat luas. Tampilan visual animasi yang ditampilkan memiliki visualisasi seperti : 1). Sejarah Singkat SMK Kartika X-1 Jakarta Barat, 2). Alamat SMK Kartika X-1 Jakarta Barat, 3). Keahlian Kompetensi SMK Kartika X-1 Jakarta Barat, 4). Fasilitas - fasilita SMK Kartika X-1 Jakarta Barat, 5). Kegiatan Ekstrakurikuler SMK Kartika X-1 Jakarta Barat.

\subsubsection{Tampilan Visual}

Tampilan Visual merupakan salah satu hasil gambar yang sudah dibuat di storyboard lalu diubah menjadi gambar digital berbasis animasi 2 dimensi, dengan bantuan aplikasi editing seperti Adobe Premiere, Adobe After Effect dan Adobe Ilustrasi, berikut ini hasil visual yang sudah selesai dan dapat ditampilkan :

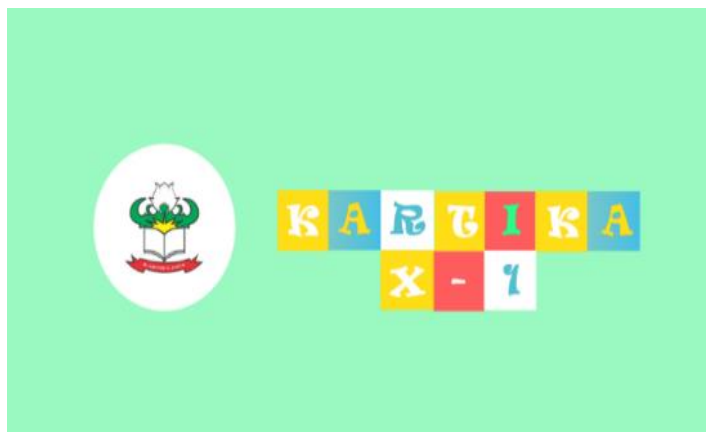

Gambar 8. /Scene 1/Menampilkan Bumper Intro

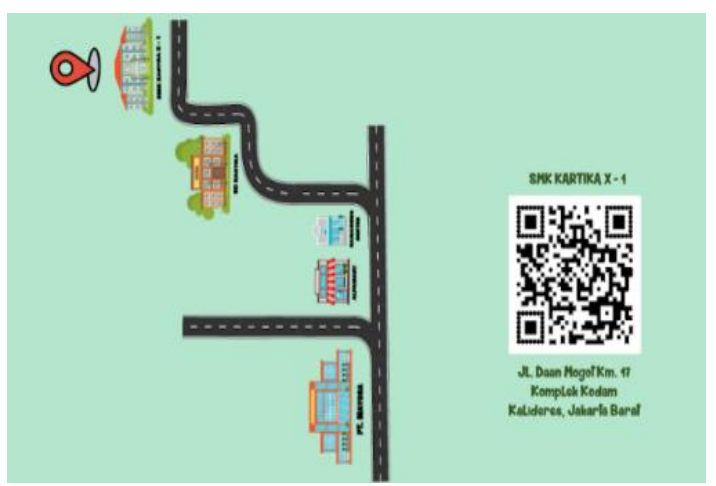

Gambar 10. / Scene 3/ Menampilkan Denah Lokasi

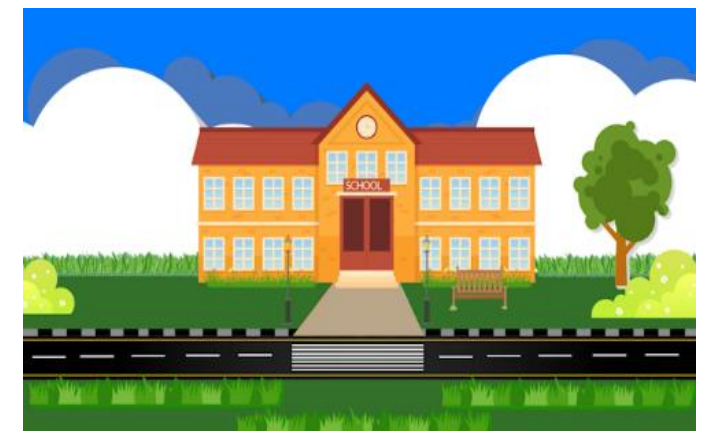

Gambar 9. / Scene 2/ Menampilkan Bangunan Sekolah

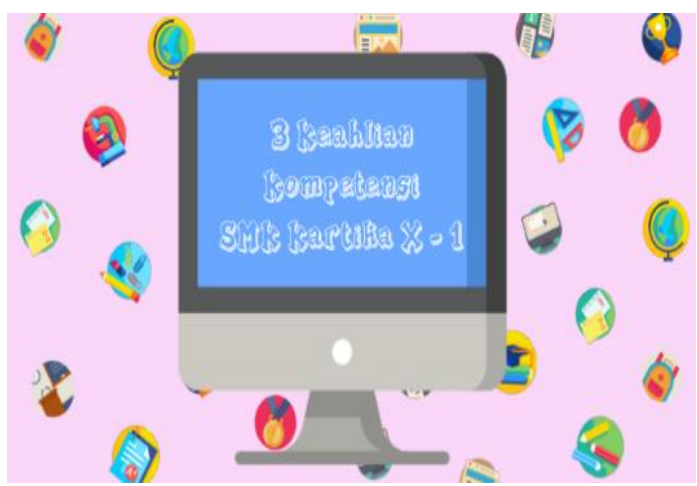

Gambar 11. / Scene 4/ Menampilkan Keahlian Kompetens 


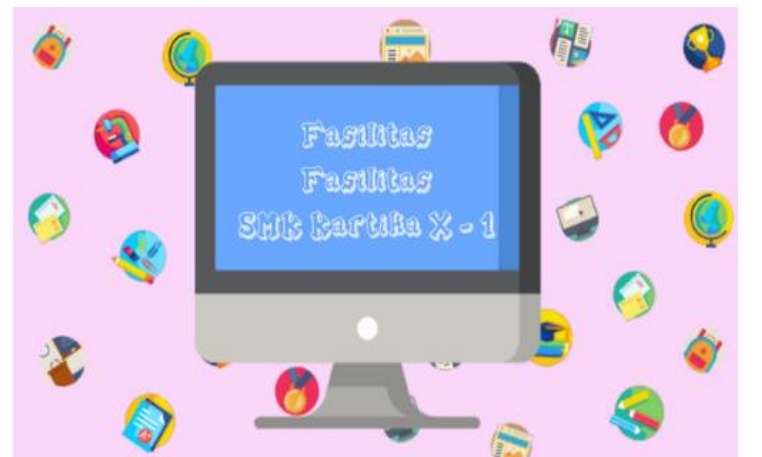

Gambar 12. / Scene 5/ Menampilkan Fasilitas - fasilitas

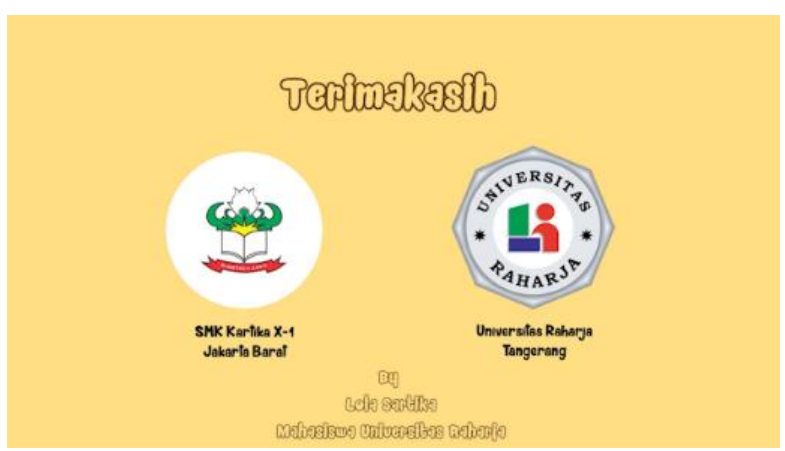

Gambar 14. / Scene 7/ Menampilkan Bumper outro atau closing

\subsection{Post Production}

Post Production merupakan suatu proses tahapan terakhir atau proses finishing dari perancangan Konsep Produksi (KPM). menghasilkan suatu karya video yang utuh dan mampu menyampaikan sebuah cerita atau pesan kepada audience. [7]

Tahapan Post Production yaitu digitizing, editing, mixing, finishing, exporting dan segmen pasar.

1) Digitizing proses memindahkan gambar manual yang diubah menjadi bentuk digital. Gambar yang dibuat di Adobe Illustrator dipindahkan ke dalam Adobe After Effect. Selanjutnya dari Adobe After Effect dimana gambar telah diubah menjadi animasi dipindahkan lagi ke Adobe Premire Pro guna untuk menjadikan file video

2) Editing proses tahapan penyambungan, pemotongan dan merangkai suatu gambar menjadi kesatuan cerita yang utuh seperti yang terdapat pada storyboard,

3) Mixing suatu proses dimana menggabungkan antara file gambar, text, audio dan sound effect digabungkan menjadi dalam 1 file

4) Finishing merupakan salah satu proses tahapan akhir atau final dari sebuah file video yang sedang dirancang

5) Exporting merupakan proses tahapan rendering atau export. Tahapan yang dilakukan export yaitu merender frame-frame video menjadi sebuah file video yang utuh, pastikan tidak ada kesalahan dalam proses editing kita (di timeline),

6) Segmen pasar adalah proses pengelompokan atau mencari target yang akan ditujukan. Hasil video informasi ini akan diupload di channel Youtube dan sosial media SMK Kartika X - 1 Jakarta Barat. [4] 


\section{KESIMPULAN}

Kesimpulan dalam pembuatan video ini memberikan informasi kepada masyarakat tentang profile dan kegiatan yang terdapat pada SMK Kartika X-1 Jakarta Barat, serta melengkapi media informasi dengan bentuk video yang berbasis animasi 2 dimensi yang sebelum nya masih menggunakan media cetak.

Strategi yang dilakukan guna untuk mencari target yang diharapkan dengan melakukan perancangan media informasi agar dapat memberikan informasi kepada masyarakat luas tentang SMK Kartika X-1 Jakarta Barat dan diharapkan dapat meningkatkan target siswa/siswi baru yang akan diimplementasikan melalui media sosial

\section{SARAN}

Disarankan kepada SMK Kartika X-1 Jakarta Barat dengan adanya media informasi berbentuk audio visual ini dapat dipergunakan dengan baik dan dapat membantu sebagai alat media promosi SMK Kartika X-1 Jakarta yang menarik minat audiens dan memperluas video company profile ini tidak hanya di media sosial saja, tetapi dapat ditayangkan di berbagai acara atau event - event dan mengupdate video company profile 1 tahun sekali.

\section{DAFTAR PUSTAKA}

[1] Agustianti, Lusi, Mahardika Rachmawan Sugandi dan Muhammad Latiful Khobir. 2016. Sinopsis, Ikhtisar, Ringkasan, Resensi dan Makalah. Bandung, Jawa Barat, Universitas Islam Negeri, Sunan Gunung Djati Bandung.

[2] Anita, Diajeng Ria dan Fitri Marisa. 2017. Rancangan Video Media Promosi Berbasis Motion Graphic 2D Untuk Meningkatkan Jumlah Mahasiswa Universitas Widyagama Malang. Journal JOINTECS. Malang, Universitas Widyagama Malang. Vol. 2 No.1

[3] Azro, Isnainy, Ir.A.Bahri Joni, Ahyar Supani, dan Meidiana Ariyani. 2020. Perancangan Video Animasi 2 Dimensi Penggalangan Dana Dari Sampah Kampus Politeknik Negeri Sriwijaya. Journal JUPITER Palembang, Sumatera Selatan, Politeknik Negeri Sriwijaya. Vol. 12 No.2.

[4] Baqi, Abdul Puad M, Mukti Budiarto dan Dinda Sumiati, 2020. Media Informasi dan Promosi Berbasis Motion Graphic pada PT. NL Indonesia. Journal CCIT. Tangerang, Universitas Raharja, Vol. 1 No.2.

[5] Kusumo, Fajar dan Sulartopo. 2019. Perancangan Video Company Profile Sebagai Media Promosi dan Informasi Pada Toko Citra Meubel Semarang. Journal Ilmiah Komputer Grafis, Semarang, Sekolah Tinggi Elektronik dan Komputer. Vol.12 No.1

[6] Supriati, Ruli, Triyono dan Dwi Afifah , 2020. Film Dokumenter Sebagai Media Informasi Dalam Memperkenalkan Tempat Wisata Banten Lama. Journal CCIT. Tangerang, Universitas Raharja. Vol. 1 No.2.

[7] Sunarya, Lusyani, Putri Apryllia dan Siti Isnaini. 2016. Desain Video Profile Based Multimedia Audio Visual And Broadcasting AS A Media Promotion. Journal CCIT, Tangerang, STMIK Raharja Tangerang, Vol. 9 No, 3 
[8] Sunarya, Lusyani, Ogi Dermawan dan Muhammad Hanif Amrullah. 2016. Desain Media Sign System dan Himbauan Sebagai Penunjang Informasi Pada Yayasan Perguruan Islam Attaqwa Tangerang. Journal Sensi, Tangerang, STMIK Raharja. Vol. 2 No. 1.

[9] Tama, Widya Kusuma Adi, Azwar Aditya Putra dan Muhamad Aziz Fikri. 2018. Video Profile Jurusan Sistem Komputer Jenjang Strata Satu Pada STMIK Raharja Tangerang. Journal Cerita. Tangerang, STMIK Raharja Tangerang, Vol.4 No. 2.

[10] Wibowo, Edi, Dewi Popi Romika dan Mega Cut Ryana. 2017. Perancangan Video Profile Sebagai Penunjang Media Informasi dan Promosi Pada SMK Citra Islami Tangerang. Journal Semnasteknomedia Online. Tangerang, Jurusan Teknik Informatika, STMIK Raharja. Vol. 5 No. 1. 